
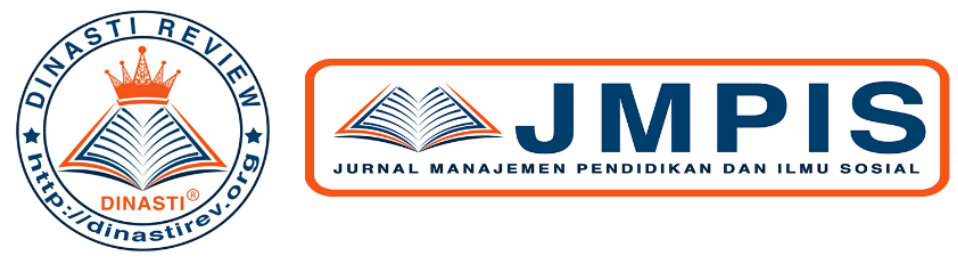

+6281387654578 ?

+6281387654578 (Q)

https://dinastirev.org/JMPIS (7)

dinasti-info@gmail.com G.

\title{
BAHAYA IMPULSE BUYING PADA PELANGGAN ONLINE SHOP SAAT PANDEMI COVID-19
}

\section{Khairunas}

PNS Pengadilan Agama Padang / Mahasiswa UPBJJ-UT Padang

\begin{tabular}{|c|l|}
\hline $\begin{array}{c}\text { ARTICLE INFORMATION } \\
\text { Received: 15 Mei 2020 } \\
\text { Revised: 25 Juni } 2020 \\
\text { Issued: } 10 \text { Juli } 2020\end{array}$ & $\begin{array}{l}\text { Abstrak: Ketika hasrat ingin berbelanja muncul, } \\
\text { pahami apa yang akan dibeli tersebut menjadi } \\
\text { kebutuhan atau hanya sekedar keinginan. Berfikir } \\
\text { agar bisa membedakan dengan rasional apakah } \\
\text { produk tersebut sangat dibutuhkan atau hanya } \\
\text { ingin memenuhi hasrat ingin membeli. Impulse } \\
\text { buying merupakan salah satu kebiasaan yang } \\
\text { banyak dimiliki oleh kalangan shopper, yang } \\
\text { mudah terpengaruh disaat membuka situs online } \\
\text { horresponding author: first authon berusaha untuk memiliki produk } \\
\text { E-mail: }\end{array}$ \\
$\begin{array}{l}\text { choirunnas165@gmail.com } \\
\text { keinginan itu dapat terpenuhi tanpa berfikir } \\
\text { panjang mengenai bahaya serta konsekuensi yang } \\
\text { akan di dapatkan. }\end{array}$ \\
Kata Kunci: Impulse buying, online shop, \\
pandemi covid-19.
\end{tabular}

\section{PENDAHULUAN}

Pelaksanaan kegiatan di rumah saja tentunya memberikan dampak dalam segala aktivitas yang dibatasi sehingga masyarakat cenderung lebih senang untuk berbelanja segala online. Hal ini tentu tidak lepas dari kebiasaan konsumen yang sering melakukan pembelian impulsive (dadakan) tanpa melihat bahaya yang akan didapatkannya.

Dalam situasi seperti ini tentu akan semakin membatasi aktivitas masyarakat di luar rumah. Yang biasanya kita dapat belanja secara langsung ke pasar atau supermarket, saat ini orang memilih untuk berbelanja online karena lebih mudah, cepat, banyak pilihan, dan yang penting tidak harus berkumpul dengan orang banyak. Di sisi lain, dengan adanya online shop muncul perilaku konsumtif dari masyarakat. Ketika berada di rumah tentunya akan memiliki banyak waktu luang dan hal ini akan mendorong kita untuk membuka online shop dan secara tidak sadar berbelanja secara berlebihan tanpa melihat kebutuhan yang diperlukan karena berbagai promo yang ditawarkan. Perilaku konsumtif merupakan kecenderungan manusia untuk melakukan konsumsi tiada batas, membeli sesuatu yang berlebihan atau tidak terencana. Pada banyak kasus, perilaku konsumtif ini tidak didasarkan pada kebutuhan, akan tetapi 
didorong oleh hasrat dan keinginan. Tentu hal ini berkaitan dengan perilaku impulse buying.

Dalam Islam terdapat perilaku dan etika konsumsi yang harus dijaga pelanggan yaitu Islam tidak mementingkan kepuasan pribadi dengan meningkatkan rasa egonya. Islam mengatur bagaimana manusia dapat melakukan aktivitas konsumsi sehari-hari sesuai dengan ketentuan AL-Qur'an dan Sunnah. Konsumsi dalam Islam tidak mengenal istilah israf (pemborosan) dan tabzir (menghamburkan uang tanpa guna), sama halnya dengan perilaku pembelian tanpa terencana (spontan) dan shopping lifestyle yang melihat bagaimana manusia untuk mengikuti alur perkembangan zaman dengan gaya hidup dalam berbelanja. Oleh karena itu diperlukan kesadaran dalam diri untuk menumbuhkan kembali religiusitas dalam berbelanja, yaitu mampu melihat tingkat maslahah dan memikirkan akibat jangka panjang. (Cucu Komala, 2018: 249)

Gaya hidup berbelanja (shopping lifestyle) yang menggambarkan bagaimana seseorang dalam menghabiskan waktu dan uang. Dengan adanya ketersediaan waktu pelanggan akan memiliki daya beli yang tinggi untuk berbelanja. Seseorang yang memiliki uang yang melimpah akan memiliki daya beli yang tinggi. Hal tersebut tentu berkaitan dengan keterlibatan seseorang untuk membeli suatu produk dan mempengaruhi pembelian impulsive. Darma L A \& Japarianto E, 2014: 80 - 89)

\section{PEMBAHASAN}

Setiap pelanggan memiliki perilaku yang berbeda-beda dalam memutuskan pembelian.Ada yang melakukan pembelian karena telah terencana sebelumnya namun juga ada yang melakukan pembelian secara mendadak ketika melihat suatu produk. Kegiatan pembelian secara mendadak, spontan, dan tidak terencana disebut dengan pembelian impulsif.

Menurut Utami, pembelian spontan atau pembelian impulsif merupakan keputusan pembelian yang dibuat oleh pelanggan secara spontan atau seketika saat melihat sebuah produk. Menurut Rook, pembelian impulsif dapat didefinisikan sebagai pembelian yang tidak rasional dan pembelian yang cepat serta tidak direncanakan, diikuti dengan adanya konflik pikiran dan dorongan emosional. Dorongan emosional tersebut terkait dengan adanya perasaan yang mendalam yang ditunjukkan dengan melakukan pembelian karena adanya dorongan untuk membeli suatu produk dengan segera, mengabaikan konsekuensi negatif, merasakan kepuasan dan mengalami konflik di dalam pemikiran. (Suharyono, 2016: 94)

Pembelian impulsif (impulsive buying) atau pembelian tidak terencana merupakan pembelian yang tidak rasional dan terjadi secara spontan karena munculnya dorongan yang kuat untuk membeli dengan segera pada saat itu juga dan adanya perasaan positif yang kuat mengenai suatu benda, sehingga pembelian berdasarkan impulsif tersebut cenderung terjadi dengan adanya perhatian dan mengabaikan konsekuensi negatif. (Fadlanil Muflih, 2018: 281)

\section{Penyebab pembelian impulsif}

Penyebab pertama yaitu suka membeli barang baru atau kecanduan belanja.. takut akan ketinggalan zaman, ingin merasa baik. ( $\underline{\text { https: }}$ //www.finansialku.com/impulsive-buying-pembelian-impulsif-solusinya/.) Banyak orang mengalami sensasi yang berbeda sementara waktu ketika mendapatkan sesuatu 
yang baru dan merasa bersemangat karena mereka dapat menggunakan barang baru. Orang-orang terpesona dengan hal-hal baru, dan mengalami hal-hal baru yang dapat menyebabkan orang merasa senang. Keputusan membeli sesuatu yang tidak direncanakan itulah yang disebut impulse buying. Kemudian orang banyak membeli sesuatu yang baru dan sedang tren di media sosial. Akhirnya karena takut ketinggalan zaman, seseorang juga terpengaruh untuk membelinya. Terkadang orang yang memiliki pengalaman tersebut akan cenderung suka belanja barang-barang baru. Pembeli impulsif juga ingin merasa baik. Pembeli impulsif biasanya selalu mencari sesuatu yang akan membuat mereka bahagia, dan kadang dengan cara membeli barang tersebut menjadi suatu cara untuk memperbaiki suasana hatinya.

\section{Kiat menghindari impulse buying}

Melihat dari penyebab yang ada terhadap pembelian impulsif, kita dapat menghindarinya dengan cara:

Pertama, hindari mengunjungi situs maupun aplikasi belanja online.Belanja online bisa di katakan berbahaya bagi konsumen yang memiliki sifat impulsif. Karena di saat membuka situs online shop, kita akan melihat berbagai penawaran produk yang branded dengan harga yang murah atau bahkan promo-promo yang menggiurkan yang membujuk kita untuk membeli produk tersebut. Tanpa kita sadari, di saat melihat satu produk yang kita butuhkan di online shop, kita pasti disuguhkan dengan penawaranpenawaran lain yang mana awalnya kita tidak berniat untuk membelinya, karena tergiur akan produk tersebut kita memutuskan untuk membelinya, padahal produk yang kita butuhkan sudah terpenuhi. Itulah yang membuat kita melakukan pembelian impulsif, yang belanja bukan karena kebutuhan tapi karena keinginan yang kuat serta dorongan untuk membeli produk tersebut. Padahal kita tidak berniat untuk membeli tapi akhirnya membeli juga. Itulah jahatnya keinginan hati.

Kedua, untuk menghindari pembelian impuls yaitu buatlah daftar dan rencana pembelian. Sebelum melakukan perbelanjaan kita harus membuat list kebutuhan yang akan kita beli. Jika ada sesuatu yang tidak ada dalam list atau daftar yang telah kita tentukan, jangan membelinya. Kita membuat daftar yang hanya berisi hal-hal yang kita butuhkan.

Ketiga, hindari pergi ke area perbelanjaan seperti mall, kecuali untuk kebutuhan. Hakikatnya, jangan jadikan berbelanja sebagai hobi ketika kita bosan. Jika kita dikelilingi oleh godaan barang-barang di mall atau pusat pembelanjaan, kemungkinan besar kita terlena akan sesuatu yang tidak kita butuhkan dalam artian sesuatu yang tidak ada dalam list kebutuhan kita.

\section{Karakteristik Perilaku Pembelian Impulsif.}

Menurut penelitian Rook, pembelian impulsif memiliki beberapa karakteristik, yaitu : spontanitas (spontaneity), pembelian terjadi secara tidak diharapkan, tidak terduga dan memotivasi konsumen untuk memiliki sekarang, seringkali dianggap sebagai respon terhadap stimulasi visual yang berlangsung di tempat penjualan; Kekuatan, kompulsi dan intensitas (power, compulsion and intensity), adanya motivasi untuk mengenyampingkan hal-hal lain dan melakukan tindakan seketika; Kegairahan dan simulasi (excitement and stimulation), keinginan mendadak untuk membeli disertai oleh adanya emosi yang dikarakteristikkan dengan perasaan bergairah dan tidak 
terkendali; ketidakpedulian akan akibat (disregard for consequences), desakan untuk membeli dapat menjadi sulit ditolak, sehingga akibat negatif diabaikan. (Rook D. W. \& Fisher R. J., 1995)

Perubahan gaya hidup yang terus berkembang menjadikan konsumen ingin selalu mengikuti perkembangannya. Kebutuhan konsumen sangat berpengaruh pada gaya hidup atau lifestyle, kegiatan shopping menjadi salah satu tempat yang paling digemari oleh seseorang untuk memenuhi kebutuhannya. Terkadang kegiatan shopping ini dilatarbelakangi oleh pola konsumsi seseorang untuk menghabiskan waktu dan uang dan berbelanja menjadi sebuah gaya hidup, kemungkinan besar shopping lifestyle ini yang menyebabkan terjadinya pembelian secara impulsive. (Aziz, 2015: 95 - 106)

Gaya hidup mencerminkan keseluruhan aktifitas individu yang berinteraksi dengan lingkungannya. Secara sadar maupun tidak sadar, gaya hidup akan berpengaruh pada keputusan pelanggan dalam pembeliannya. Masing-masing individu memiliki karakteristik kepribadian yang berbeda yang juga mempengaruhi pembeliannya. (Almi $\mathrm{N}, 2012: 13$ )

Dengan melihat dari kejadian tersebut tentu ada bahayanya bagi kita. Jangan hanya sekedar mengikuti nafsu semata, senang semata tanpa memikirkan apa yang akan terjadi terhadap diri kita dengan mempunyai sikap impuls. Apalagi di era pandemi covid 19 sekarang ini, segala sesuatu harus difikirkan terlebih dahulu. Tanpa kita sadari, di balik kesenangan yang kita lakukan ada bahaya yang akan mengancam kita jika selalu berperilaku impulse buying.

\section{Bahaya impulse buying}

Pertama, jika kita sudah terbiasa berada di pusat perbelanjaan kita akan cenderung untuk membeli sesuatu yang mana produk tersebut diluar kebutuhan kita melainkan keinginan semata. Impulse buying menjadi bahaya lantaran kita yang suka mengikuti gaya hidup konsumtif yang bisa merugikan diri sendiri. Dalam Islam telah dikatakan bahwa sikap yang berlebih-lebihan itu disebut tabzir dan itu dosa.

Kedua, setelah melakukan pembelian impulsive, timbullah penyesalan pembelian, dimana dirasa barang yang dibeli atau produk yang telah dipesan di online shop dan sesampainya produk itu di rumah ternyata produk tersebut terlihat biasa saja, Awalnya berharap mendapat kepuasan ternyata berubah menjadi penyesalan.

Ketiga, tentunya bahaya bagi keuangan. Pembeli impulsif akan mengalami permasalahan dengan keuangannya. Tidak terkendalinya perilaku impulsive membuat kita menderita dalam hal keuangan. Karena banyaknya pengeluaran tidak terencana yang akhirnya berhutang untuk menutup kebutuhan. Jika keuangan tidak bisa dikendalikan, maka bisa terjerat hutang.

\section{PENUTUP}

\section{Simpulan}

Perilaku pembeli impulsive cenderung melakukan transaksi secara spontan atau mendadak.Mereka melakukan pembelian tidak dengan sesuai kebutuhan melainkan sesuai keinginan.Pada kondisi sekarang ini, belanja di rumah lebih dianjurkan karena keterbatasan yang tidak bisa bertransaksi di luar rumah. Bisnis online saat ini memang sedang menjamur di kalangan masyarakat, mulai dari jual beli kebutuhan pokok seperti 
makanan ringan, baju dan lain-lain. Semuanya bisa diperoleh dengan mudah, hanya dengan satu klik semua bisa terbeli.

Perilaku pembeli impulsive dapat membahayakan diri sendiri. Pertama, pelaku impulsive akan terbiasa dengan gaya hidup konsumtif yang bisa memberikan dampak negatif terhadap diri sendiri. Kedua, akan ada rasa penyesalan disebabkan karena adanya produk yang tidak sesuai dengan ekspetasi. Ketiga, akan memperburuk keuangan, karena tidak dapat menahan diri untuk melakukan pembelian diluar dugaan.

\section{DAFTAR PUSTAKA}

Almi N, the Influence Of Lifestyle To The Purchase Decision Of Kawasaki Ninja Bikes In Pekanbaru", Jurnal Manajemen Pemasaran, 2012.

Aziz, VRA, Pengaruh Persepsi Risiko dan Gaya hidup terhadap Keputusan Pembelian Pakaian Secara Online Melalui Blackberry Messenger, eJournal Psikologi, 2015.

Darma L A \& Japarianto E,Analisa Pengaruh Hedonic Shopping Value Terhadap Impulse Buying Dengan Shopping Lifestyle Dan Positive Emotion Sebagai Variabel Intervening Pada Mall Ciputra, Jurnal Manajemen Pemasaran, Vol. 8, No. 2, 2014

Muflih, Fadlanil, Analisis Pengaruh Faktor Situasional terhadap Pembelian Impulsif Pada Binjai Supermall, UIN Sumatera Utara, At-Tawassuth, Vol. III, No. 2, 2018

Rook, DW, \& Fisher, R.J, Normative Influences on Impulsive Buying, Journal of Consumer Research, Vol. 22, 1995.

Suharyono, Analisis Faktor-faktor yang Berpengaruh Terhadap Pembelian Impulsif (Survei pada Pengunjung yang Melakukan Pembelian Impulsif di Distro 3second Cabang Mall Olympic Garden Malang, Jurnal Administrasi Bisnis 36, No. 1, 2016.

Reaksi konsumen secara spontan, segera dan cepat.

Perilaku konsumen untuk membeli secara dadakan.

Moody Konsumen yangn positif berpengaruh terhadap perilaku impulsive dalam membeli produk. Sifat hedonis, keinginan untuk menjekajah memperoleh pengalaman baru, kesenangan berpengaruhn terhadap 